\title{
Design of an Intelligent Educational Resource Production System
}

\author{
https://doi.org/10.3991/ijet.v13i12.8914 \\ Brahim Faqihi $\left.{ }^{\bowtie}\right)$, Najima Daoudi, Rachida Ajhoun \\ University Mohammed V - Souissi Rabat Morocco. \\ brahimfaqihi@hotmail.com
}

\begin{abstract}
In the field of learning, we are witnessing more and more the introduction of new environments in order to better meet the specific needs of the main actors of the process. The shift from face-to-face learning to distance learning or e-learning has overcome some of the challenges of availability, location, prerequisites, but has been rapidly impacted by the development of mobile technology. As a result, m-learning appeared and quickly evolved into p-learning.

The arrival of the "Open Software" concept has given birth to several "opensomething" initiatives, among which are the Open Educational Resource (OER) and the Massive Online Open Course (MOOC). These learning resources have also made progress, although they are fairly recent. Admittedly, this diversity of environments offers a wealth and a multitude of pedagogical resources. However, the question of the capitalization of contents, knowledge and know-how of each of these environments is necessary. How can the exchange and reuse of pedagogical resources be guaranteed between these different learning environments? otherwise-said how to guarantee the interoperability of these resources? In order to contribute to the creation of an pedagogical heritage, we propose to design a casebased system allowing the author, when creating a course in a particular context and environment, to exploit the resources that are already available. The goal is to put in place an intelligent production system based on case-based reasoning. It is based on four phases ranging from indexing to reuse, through the similarity measurement and the evaluation.

In the first part, we will detail the evolution of learning environments. In the second part, we will review the existing course production platforms, their principles and their challenges. In the third part, we will present case-based reasoning systems, and then we will introduce our target system.
\end{abstract}

Keywords-Learning, case-based system, reuse, capitalization, pedagogical resources, course production.

\section{Introduction}

At the present time, we are witnessing a proliferation of resources and learning environments that offer such rich and varied content. Thus, the role of the author, an indispensable player in learning is evolved. Will its role be limited to the production of content, knowledge and know-how in a given environment? it is certain that the reuse 
of existing resources will be part of it. It is interesting to capitalize on this production and to exploit it in other situations or contexts of learning. This reuse will allow authors to improve existing production, adapt it to the contexts in which they find themselves and focus on new and advanced pedagogical objectives. We are interested in our laboratory in the development of intelligent learning systems. And we are interested in the development of an intelligent production system for the author focused on the specificities decided at the time of the launch of the research in a heterogeneous environment of learning platform consisting of e-learning platform, MOOC and Open Educational Resources (OER).

The basic questions of this paper are: How to design an intelligent course production system on behalf of the author to search heterogeneous learning environments? How to hide the heterogeneity of structures? How can we have a result that meets the need of the author? How can the production task be made easier and provide him with the opportunity to perfect and better adapt the found resource to its context? How to re-use an pedagogical resource located in a learning platform?

Thus, we aim in this paper, the design of an intelligent system able to support, to facilitate for the author the phase of the production of courses.

This article is structured in four sections: in the first section, we will review the evolution of learning environments as well as the richness and importance of their content. In the second section, we will discuss existing content production systems, their operating principles and their limitations. In the third section, we will detail through a state of the art, the principle and evolution of case-based systems and we will propose our vision for the intelligent production system in the fourth section. Finally, we will conclude our article with some perspectives on future actions.

\section{Evolution and richness of learning environments}

Our vision is to design an intelligent system capable of assisting the author as one of the main actors in the learning process during the course production phase. First, we aim to capitalize and reuse the existing resources. Then, we want to facilitate the production task to the author and offer him more opportunity to adapt and enrich the resource than to reproduce it. We consider that the reproduction of a resource similar to an already existing resource is a waste of time for the author as well as for the learners. Today with the advent of information and communication technologies, learners can be very knowledgeable when participating in a course. The author must therefore have much more time for adaptation, improvement and refinement of the resources to make it adequate with the context of use. We remind that we will deal with OERs and elearning resources and MOOCs. In what follows, we will return to the evolution of these learning environments. 


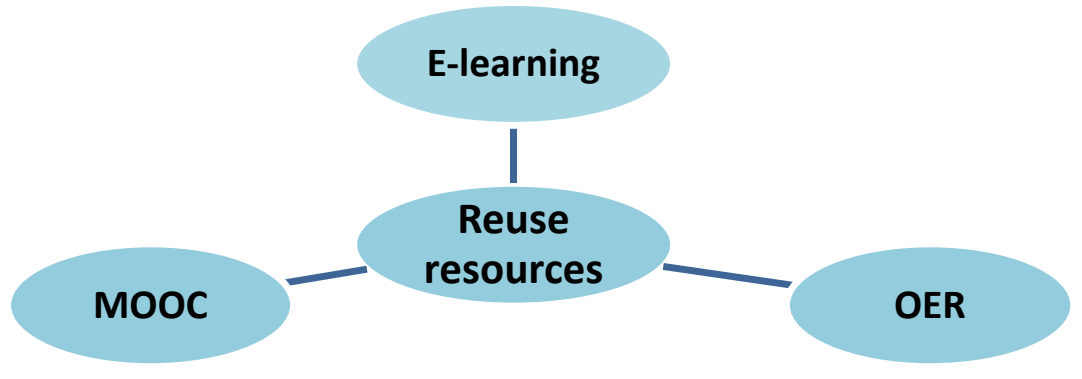

Fig. 1. Diagram of treated learning environments

\subsection{Evolution of distance learning}

The distance learning has overcome all the barriers of time and space constraints for traditional or classic learning. The multiple evolutions of the technology have greatly helped the companies, universities and all interested people to benefit, to follow and to acquire eternally the knowledge, skills and experience under different types: Basic training or continuing education. E-learning has been a result of the development of ICTs for learning.

The beginning of distance learning was marked by correspondence learning to arrive at e-learning in the first decade. Its switch to d-learning, m-learning or p-learning was strongly linked to technological progress. Today, the trend is to return to the initial concept of e-learning which has become a concept that includes all types of learning, already cited, despite the multitude of technologies. Indeed, although the technologies differ, we always talk about the same concept and the same learning content. These learning modes have one thing in common which is the infrastructure or the network and the subject matter that is the pedagogical content. Fig. 2 illustrates the evolution of distance learning:

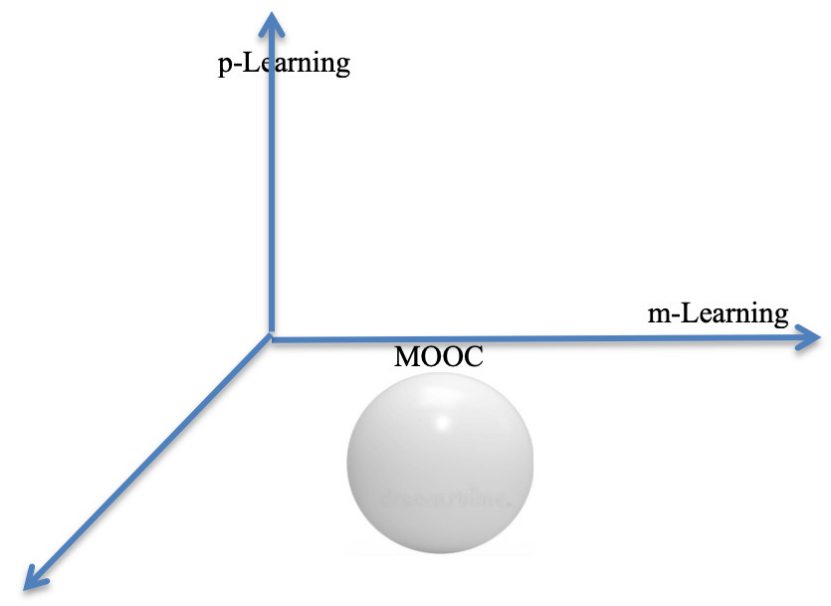

Fig. 2. Evolution of distance learning 
The e-learning in the era of cloud computing has almost the same problems as elearning to m-learning regardless of technology and services. E-learning in a cloud environment, can use either services, platforms or infrastructures. The cloud computing has provided e-learning with new opportunities in terms of infrastructure, platforms and services. The cloud computing will hide the problems related to each of these levels. In fact, it eliminates the difficulties related to the maintenance of content servers, the management and administration of learning platforms and it offers a costs reduction since only the services used are paid.

Today, with the mobility of tutors and the progress of mobile technology, a tutor can work on multiple platforms. It must have the possibility, when creating an pedagogical content, to capitalize first on the existing. However, when we talk about the existing is not necessarily in the platform where he wants to create content but in any type of platform that it meets a standard or not.

The development of mobile technology as well as the advances made in the field of web services have allowed e-learning another opening and other facilities for communication, sharing, availability of contents, speed of dissemination on the social networks. This gave birth to e-learning 2.0. Initially, the platforms started with simple websites, but they developed into specialized learning platforms. Today there are specialized platforms for managing collaborative content in several ways.

\subsection{Evolution of pedagogical resources}

The trend of the 2000s was much more oriented towards collaborative work. This has further expanded the spectrum of e-Learning and made transformations in the roles of stakeholders in these environments.

In 2012, they were defined as follows: "Teaching, learning and research materials on any medium, digital or otherwise, existing in the public sector or published under an open license allowing access, use, adaptation and free redistribution by others, without restrictions or with limited restrictions. "(UNESCO 2012). Today many universities have begun to trust open resources. The richness of their contents and the freedom of access have made them very widespread. the MOOCs have been widely used by pedagogical institutions. Their evaluation principles, the richness and the importance of their contents have made them part of the academic curriculum. In this multitude of learning environments and the wealth of content, we want to reuse and capitalize these already existing resources. We note the existence of an interesting content that we want to reexploit and save the author the reproduction of content that already exists.

\section{Learning Content Production Platform: The Author a Leading Actor}

In the field of platforms dedicated to e-learnin and MOOCs there are two main categories: the first category is that of so-called "proprietary" platforms, which means that the source code owns the publisher. The second category offers open-source solutions for which the code is accessible and modifiable. The four main platforms, free and 
open, specialized in e-learning and MOOC, are the following: CLAROLINE, GANESHA, MOODLE and OPEN EDX. However, the EDOs do not have a specific platform. Table 1 includes the platforms studied.

Table 1.

\begin{tabular}{|l|l|l|l|}
\hline Resource Type & MOOC & e-learning & OER \\
\hline Plateform & Open Edx & MOODLE, CLAROLINE, GANESHA & Do not have a specific platform \\
\hline
\end{tabular}

\subsection{State of the art}

In what follows, we will describe each platform with its functionalities that are related to the production of content:

CLAROLINE, developed in 2002 by the Leuven University in Belgium. It allows the creation of online course spaces and the management of training activities on the Internet. It is supported by an important global community because it is translated into 35 languages. It is used by several institutions in 84 countries. With no license fee, it creates workspaces and online courses.

MOODLE is used to create communities of learners around content and pedagogical activities. It has a powerful content management system and offers interactions between educators, learners and pedagogical resources to form a network or community around a theme. This feature is undeveloped in other platforms.

Open edX, although its interface is sober, it is a little star of the sector. It offers all the functions that can be required of such a platform. Founded by the Massachusetts Institute of Technology (MIT) and Harvard University, it is widely deployed internationally. Through its community, it is in continuous improvement. The road map of developments reflects the major changes underway. Its installation takes time and requires expertise in system administration and the Python programming language. The researchers are conducted by a team of researchers [44] have described the Open edX platform as the most widely used platform. This result is obtained due to an analysis made on the various CLOM platforms likely to serve as a technological base for a pilot project: Open edX, OpenMOOC, Racing Builder, Canvas, Udacity, Coursera, FutureLearn, Moodle, Sakai, WordPress and SPIP. The criteria on which this choice is based are: the modern software architecture, opening, robustness, scalable to large groups for a cloud deployment, ease of use and ergonomics for course designers and learners, the license strategy allows the platform to be adaptable and, finally, the guarantee of durability, thanks to the endorsement of important stakeholders such as Harvard, MIT, Stanford, Google and FUN.

GANESHA is a LMS distance training created by the company Anema. It allows a trainer or training department, the implementation of a module with course materials, supplements, quizzes, tests and collaborative tools.

The following table Table 2 summarizes the main functions identified in each platform: 
Paper-Design of an Intelligent Educational Resource Production System

Table 2. Synthesis on the main functionalities offered by the studied platforms (https://www.construction21.org/france/community/pg/pages/view/23457/ )

\begin{tabular}{|c|c|c|c|c|}
\hline & OpenEdx & CLAROLINE & GANESHA & MOODLE \\
\hline Creation date & 2013 & 2001 & 2001 & 2002 \\
\hline Main language & Python & PHP & JAVA & PHP \\
\hline $\begin{array}{c}\text { Course Creation } \\
\text { Tool }\end{array}$ & $\begin{array}{c}\text { Simple use. Can } \\
\text { become complex } \\
\text { with many mod- } \\
\text { ules to add }\end{array}$ & $\begin{array}{l}\text { Works according to the } \\
\text { concept of space associ- } \\
\text { ated with a course or an } \\
\text { pedagogical activity }\end{array}$ & \begin{tabular}{|} 
Provides interfaces to \\
create one or more \\
modules for one or \\
more groups
\end{tabular} & $\begin{array}{c}\text { The courses are } \\
\text { created by adminis- } \\
\text { trators, courses cre- } \\
\text { ators or managers }\end{array}$ \\
\hline $\begin{array}{l}\text { Navigation in the } \\
\text { course }\end{array}$ & Hierarchical & Ergonomic & $\begin{array}{c}\text { Only the administra- } \\
\text { tor who can configure } \\
\text { online training }\end{array}$ & $\begin{array}{l}\text { User-friendly and } \\
\text { easy to move } \\
\text { around the tree } \\
\text { structure (depend- } \\
\text { ing on the user's } \\
\text { role)) }\end{array}$ \\
\hline $\begin{array}{l}\text { Allows peer evalua- } \\
\text { tion }\end{array}$ & $\begin{array}{c}\text { yes (feature to add } \\
\text { and complex to } \\
\text { set) }\end{array}$ & \begin{tabular}{|c|}
$\begin{array}{c}\text { Yes (Includes tools spe- } \\
\text { cific to collaborative } \\
\text { pedagogy) }\end{array}$ \\
\end{tabular} & Track learners & $\begin{array}{l}\text { Yes (This is the } \\
\text { role of the Work- } \\
\text { shop activity) }\end{array}$ \\
\hline WIKI & Yes & Yes & No & Yes \\
\hline $\begin{array}{l}\text { Workgroups Man- } \\
\text { agement }\end{array}$ & $\begin{array}{c}\text { Yes (newly devel- } \\
\text { oped functional- } \\
\text { ity) }\end{array}$ & Yes & Yes & Yes \\
\hline Chat & maybe added & $\begin{array}{c}\text { Yes (Video and text } \\
\text { chat) }\end{array}$ & Yes (little ergonomic) & Yes \\
\hline $\begin{array}{c}\text { Badges system to } \\
\text { unlock }\end{array}$ & $\begin{array}{l}\text { No (being imple- } \\
\text { mented) }\end{array}$ & - & No & $\begin{array}{l}\text { Yes (Requires the } \\
\text { administrator role) }\end{array}$ \\
\hline $\begin{array}{l}\text { SPOC / private } \\
\text { space }\end{array}$ & Yes, but not tested & Yes (Extranet) & Yes & Yes \\
\hline Social Learning & No & - & - & No \\
\hline $\begin{array}{l}\text { Compatibility } \\
\text { SCORM (standard } \\
\text { of e-learning) }\end{array}$ & No & Yes & Yes & Yes \\
\hline $\begin{array}{l}\text { Interface with the IS } \\
\text { and accepted stand- } \\
\text { ards }\end{array}$ & & $\begin{array}{l}\text { WAI, SCORM } 1.1 \& \\
\text { 1.2, LDAP, SSO, Shib- } \\
\text { boleth, LCS, IMS/QTI, } \\
\text { CSS, HTML, RSS }\end{array}$ & $\begin{array}{l}\text { LOM, SCORM 1.2, } \\
\text { SCORM } 2004\end{array}$ & $\begin{array}{l}\text { SCORM 1.2, } \\
\text { WebCT, Black- } \\
\text { board }\end{array}$ \\
\hline $\begin{array}{c}\text { Server operating sys- } \\
\text { tem }\end{array}$ & $\begin{array}{c}\text { Ubuntu/Linux } \\
14.04\end{array}$ & $\begin{array}{c}\text { Linux (Ubuntu, Man- } \\
\text { drake, Red Hat, Suze), } \\
\text { Mac (OS X), Windows } \\
(9 x, \text { Me, NT4, 2000, } \\
\text { XP) }\end{array}$ & \begin{tabular}{|c|} 
Unix, Linux and Win- \\
dows
\end{tabular} & $\begin{array}{l}\text { Unix, Linux et } \\
\text { Windows }\end{array}$ \\
\hline Customer Post & $\begin{array}{c}\text { Chrome, Firefox, } \\
\text { Safari or Internet } \\
\text { Explorer (version } \\
9+)\end{array}$ & No restriction & $\begin{array}{c}\text { Mozilla Firfox } 1.5+ \\
\text { Internet Explorer } \\
1.7+ \\
\text { Google Chrome }\end{array}$ & \begin{tabular}{|c|} 
Mozilla Firfox $4.0+$ \\
Internet Explorer \\
$8.0+$ \\
Google Chrome \\
$11.0+$
\end{tabular} \\
\hline $\begin{array}{l}\text { Application sur An- } \\
\text { droid }\end{array}$ & Yes & Yes & No & $\begin{array}{l}\text { Yes, Moodle Mo- } \\
\text { bile }\end{array}$ \\
\hline
\end{tabular}




\subsection{Challenges of platforms}

Despite the advantages of open source platforms, they also have certain limitations. Which are distinguished as shown in Table 3.

Table 3.

\begin{tabular}{|c|c|c|c|}
\hline CLAROLINE & GANESHA & MOODLE & OPEN EDX \\
\hline $\begin{array}{l}\text {-The workspaces remain } \\
\text { partitioned, a space man- } \\
\text { ager cannot copy the in- } \\
\text { formation he has created } \\
\text { in another space (sched- } \\
\text { ule, ads, html pages). } \\
\text { - Ergonomic interface of } \\
\text { learning paths to im- } \\
\text { prove ... too many } \\
\text { screens to reach the con- } \\
\text { tent. If the resource has } \\
\text { many items, there is no } \\
\text { dynamic menu, it's a lot } \\
\text { of scrolls and clicks to } \\
\text { follow the course. } \\
\text {-The SCORM is not } \\
\text { fully interpreted by the } \\
\text { platform. }\end{array}$ & $\begin{array}{l}\text {-The Instructor-tutors can } \\
\text { not set their courses inde- } \\
\text { pendently, only the plat- } \\
\text { form administrator can } \\
\text { organize online training } \\
\text { unlike many other plat- } \\
\text { forms. It is an organiza- } \\
\text { tional choice to consider. } \\
\text { - Limited internal mes- } \\
\text { saging (sending only one } \\
\text { file at a time, but possi- } \\
\text { bility to send a com- } \\
\text { pressed file of several) } \\
\text {-Authentication: pass- } \\
\text { words of unencrypted us- } \\
\text { ers. }\end{array}$ & $\begin{array}{l}\text {-Possibility of positioning test } \\
\text { but manual management, no } \\
\text { automatic route assignment } \\
\text {-For teachers, the diversity } \\
\text { and specificity of all tool set- } \\
\text { tings may seem too complex } \\
\text { for users who are less famil- } \\
\text { iar with ODL. However, } \\
\text { many online tutorials exist, it } \\
\text { is also important that the plat- } \\
\text { form administrator or project } \\
\text { coordinator be available to } \\
\text { help teachers understand the } \\
\text { full functionality of Moodle. } \\
\text { To avoid failures, one of the } \\
\text { first courses to install on the } \\
\text { platform is the one about us- } \\
\text { ing Moodle. }\end{array}$ & $\begin{array}{l}\text {-The majority of } \\
\text { courses are in English, } \\
\text { which may limit the } \\
\text { access. } \\
\text {-Sometimes the certifi- } \\
\text { cate is conditioned by } \\
\text { the payment (espe- } \\
\text { cially those of Harvard } \\
\text { or MIT). However, } \\
\text { there is the option to } \\
\text { print the transcript in } \\
\text { order to attest the suc- } \\
\text { cess. } \\
\text {-Forums are not al- } \\
\text { ways practical accord- } \\
\text { ing to their size. }\end{array}$ \\
\hline
\end{tabular}

As we mentioned in the first section, we will discuss the reasoning systems based on use cases. We consider that the reuse of a resource in another context and another environment other than its own, is a case of use that will subsequently improve the quality of the search and the choice of the relevant resource for an author. In the following, we will present a state of the art of these systems and then we will propose the architecture of our target system.

\subsection{Synthesis}

In this comparative study, we focused on open source and public platforms that are the best known and most widely adopted by leading universities around the world. The study took into consideration the following components: pedagogy, tutoring, communication, collaboration, planning and administration.

We recall that our goal is the reuse of pedagogical resources when switching from one platform to another. However, through this study, we found that it is impossible to communicate resources between these platforms. Although some environments support some standards, this is not enough to reuse platform resources in another platform. So the resources exist but they are dispatched. So, we want to have a system of intelligent production that aggregates these four environments and provides us with a case base where each resource is enriched by its use cases. In other words, a module that will promote reuse by taking into account the specification of each platform. 


\section{$4 \quad$ Design of use case systems}

The general principle of case-based reasoning or Case-Based Reasoning (CBR) is based essentially on experiences described through fully structured formats such as objects or records extracted from a database. In parallel with this, other models wanted to go beyond the limits of this structural approach and allow this principle to be extended to more varied fields. In this part, we pass a succinct presentation of the general principle of case-based reasoning, we present projects built on this principle.

\subsection{Principles of case-based reasoning}

The principle of CBR case-based reasoning is an approach that aims to solve problems based on past experiences in solving new problems [34]. Past experiences form what is called a case base. Concretely a case is built on the basis of two part a "problem" and a "solution" that remedies a specific situation. This case can also describe the benefits of applying the solution. The techniques used for CBR make it possible to propose new solutions by widening the problem to similar situations. The basic principle of the CBR has its foundation of cognitive science research driven by Roger Schank during the eighties. [35]

\subsection{Components of a case-based system}

In general, a CBR is a suite of processes and also knowledge that aims to capitalize on past experiences. The following figure Fig.3 presents the generic model of a CBR system as well as the main processes that constitute it:

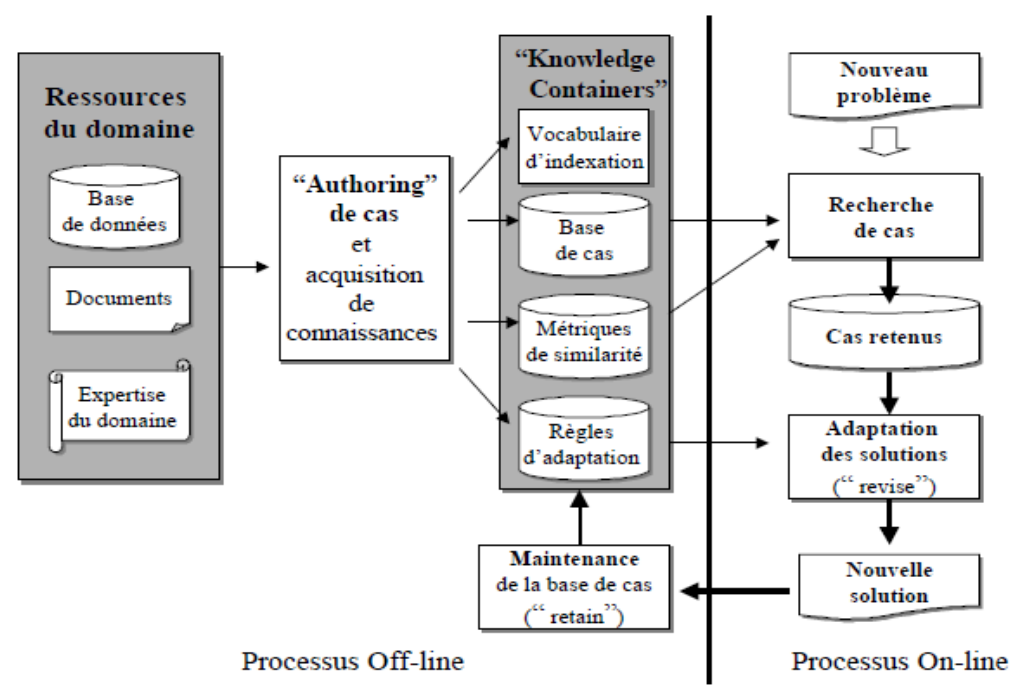

Fig. 3. Generic model of a CBR system [39] 
A CBR system uses four categories of knowledge ("knowledge containers"). They are grouped as follows:

- indexing vocabulary: To characterize the problem description and solutions of the domain we will need a list of attributes or features that play an important role during the research phase.

- case base: All the structured experiences already passed will be exploited during the other phases: Research, adaptation and maintenance.

- Similarity measures: These are the functions that allow the evaluation of the degree of similarity between two or more cases. These measurements are used during the research phase in the case base. They are essentially based on the features.

- adaptation knowledge: These are heuristics of the treated area. In general, they are in the form of rules that allow modification and evaluation of applicability in new situations.

\subsection{Design of an Intelligent Production System based on CBR}

We recall that our goal is to deal with pedagogical resources related to certain learning environments. We must therefore look for a way to make these resources usable during the migration of an EAi to an EAj. We want to capitalize on existing production. For example, a tutor who has produced a course in e-learning, and he has migrated to POOC, he must have the opportunity to reuse this resource and not create a new course dedicated to the new learning environment according to a new structure. The multitude of environments engenders behind a multitude of pedagogical resources. Not to mention that each resource has its own pedagogical goals. How to make the most of pedagogical resources when producing courses in a pedagogical environment on the author's side? We have a concern to capitalize and mutualize the efforts and minimize the investments of the authors. It is thought to reuse all that already exists with communication with learning environments. It is the foundation of the concept of interoperability. But since we are in the pedagogical field, semantics is a great importance since the pedagogical objectives have a meaning that must be preserved. The use of XML files has been able to overcome syntactical conflicts. In addition, without semantics we can't achieve interoperability between pedagogical objectives.

OERs, in turn, are also rich learning content that must be reused. This requires semantic interoperability between OERs and MOOCs.

OERs have their own structures and metadata; So we have different learning environments where each environment has its own resources and therefore different representations. There is often a need to produce a new course expressed by the authors. For example a resource in MOOCs has its own metadata similarly for e-learning or OER; There are several works concerning the use of OERs and MOOCs.

We have found, therefore, that CBR systems have a great contribution in the field of Artificial Intelligence. We propose to use these systems to solve our problem. As mentioned in the previous paragraphs, the principle of case-based systems is essentially based on the use cases. 
An author who wants to reuse an already existing resource, the cases of use of the resource in question is for him an important indicator on which he can be based to reuse this resource or not. Its use in another context is a case of use of the resource. This positively impacts its importance, its ability to adapt and finally its relevance. As a result, when an author wants to produce a pedagogical content, it is important to first capitalize on existing production. So he has to do a search according to his own pedagogical goals. The result is a set of resources that do not exactly meet the needs initially expressed by the author. In order to bring the result closer to the teaching objectives, an indexing action is essential in order to have a sorting by relevance. During this phase, a pedagogical intervention by an expert is essential. Some researchers have also mentioned the notion of loyalty. In other words, actors who often contribute content that is considered interesting can benefit from a privilege of acceptance of their proposal. Figure 4 illustrates our vision.

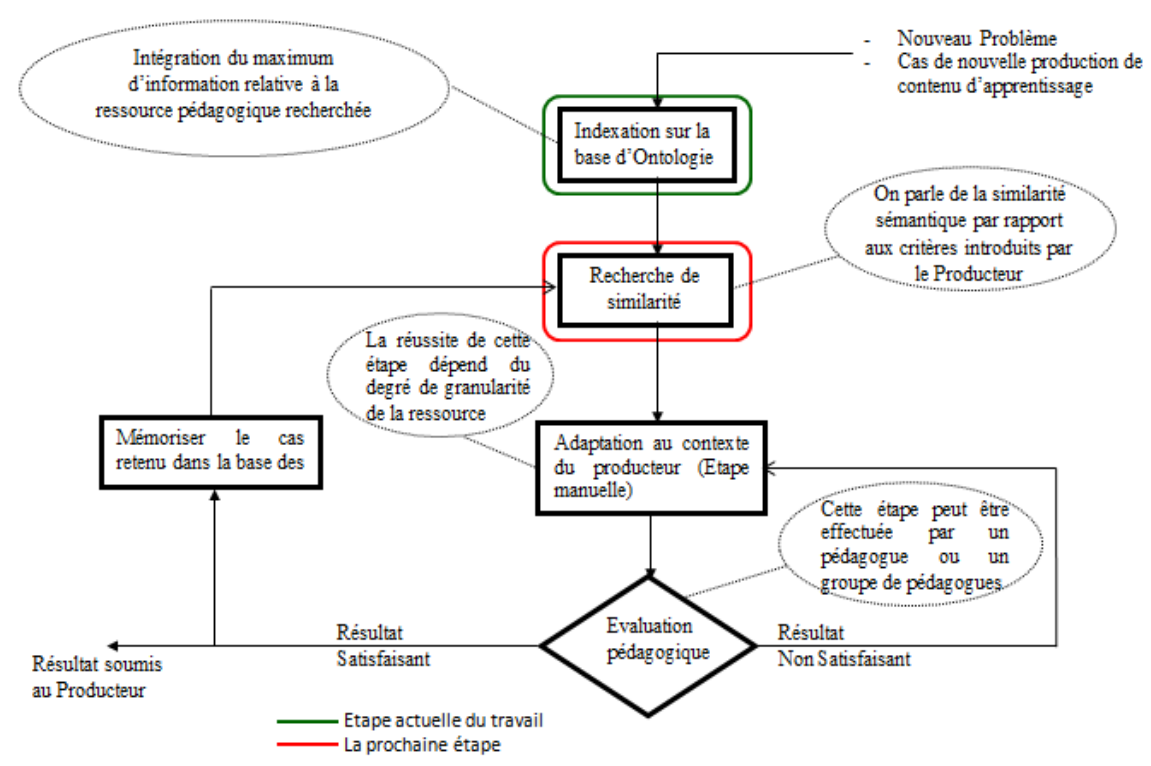

Fig. 4. Scenario of production of learning content through case-based reasoning.

Indexing - semantics. This action will be based on the keywords or pedagogical objectives sought and performs an indexing of the pedagogical content. In order to avoid syntax problems, we propose a list in which the producer chooses the keywords by which he wishes to carry out the search. In case, he wants to introduce a term that is not in the list, an administrator will update the keyword database before giving the hand to the producer to start his search.

Similarity search. This phase, will search in an already obtained indexed content, to avoid redundancy, and extract all the resources having a similarity with the pedagogical objectives set by the author. The documents are classified according to the chosen method: decimal or universal decimal; 
The research or similarity function: In this phase and through the specific keywords and objectives specified by the author, we will model a search function that will draw from the three learning environments concerned by this paper and return to us. the resources found, at this stage we will need an ontology that will model this research.

Choice and validation. This phase requires the intervention of an expert. It is a manual operation that aims to select and validate the pedagogical resources responding to the need expressed by the author. However, we can sort, based on the use cases of the resource, its annotations, tags or comments if they have exploitable, but human intervention is essential. Indeed, the author is the only actor able to measure the utility of the resource in its context apart from its ranking in the research.

Reuse and enrichment. A use of the resource when creating pedagogical content is a case of using the resource. In this phase, we enrich a resource use bank by this use case. Indeed, a use case is a successful experience of the resource. It is also an indicator for content producers. The resources which are already reused and enriched will be considered in the future as a research environment among existing ones. Searching in an environment that contains the resources already in use can be very beneficial for the author to perform a simple search on a given platform.

\section{Conclusion}

In this paper, through a comparative study of learning platforms, we have identified the common elements and divergences that exist between learning platforms on the content production side and we have noted the difficulty of reusing pedagogical resources during production in learning platforms. We proposed a solution based on the artificial intelligence to know the reasoning based on case. We focused on the architecture of the case-based production system and detailed its steps. Currently we are finalizing the design of the ontology which is the phase of development to then begin the next three stages namely: Research, Validation, Reuse and enrichment.

In future works, we will further detail the first step of this system by proposing a conception of a formalism able to group together the maximum common concept of a pedagogical resource.

\section{References}

[1] Atkins, DE, Brown, JS, and Hammond, A. L (2007). A review of open educational resources (OER) movement: achievements, challenges and new opportunities. Report to the William and Flora Hewlett Foundation. Retrieved November 28, 2015, against http://www.hewlett.org/uploads/files/ReviewoftheOERMovement.pdf

[2] Yuan, L., \& Powell, S. (2013). MOOCs open education and: implications for higher education. A white paper. Retrieved March, 9 from http://publications.cetis.ac.uk/2013/667

[3] Rodés, V., Mustaro, PN, Silveira, FI, Omar, N., \& OCHOA, X. (2014). instructional design templates to support books, Open Collaboration for Open Education. Proceed-ings of Interaccion'2014, Tenerife, Spain, 2014, paper \# 93. Retrieved March, 12, 2016 from $\mathrm{http}: / / \mathrm{dl}$.acm.org/citation.cfm?id=2662346\&CFID=761853641\&CFTOKEN=55770594 
[4] From La Passardière, B. Jarraud, P. ManUeL, a LOM application profile for C@ mpuSciences. Science and Technology of Information and Communication for Educa-tion and Training, Volume 2004. Available At http://sticef.univ-lemans.fr/num/vol2004/passardiere-11/sticef 2004 passardiere 11p.htm

[5] Burgos, D., Michel Arnaud, M., Patrick Neuhauser, P. Koper, R. (2005) IMS Learning Design: Pedagogical flexibility at the service of the needs of e-learning. EPI Associa-tion December 2005. Available at http://www.epi.asso.fr/revue/articles/a0512c.htm

[6] Pernin, J-P. (2004). LOM, SCORM and IMS-Learning Design: resources, activities and scenarios. Report written by the enssib from a transcription of the oral communica-tion of JeanPhilippe Pernin on November 16, 2004. Available at http://www.enssib.fr/bibliothequenumerique/document-1239

[7] N. Daoudi "MADAR Learning: Interoperable learning environment between E-learning and M-learning". PhD thesis in computer science. National School of Com-puter Science and Systems Analysis, Morocco, 2009.

[8] Berners-Lee, T. (2001). The semantic web. Scientific american , pp. 284(5):35-43,.

[9] A. ELBYED "ROMIE, an instance-based ontology alignment approach". PhD thesis in computer science. the S \& I doctoral school in co-accreditation with the UNIVERSITY OF EVRY-VAL D'ESSONNE, Paris-Sud, France, 2009.

[10] Jos de BRUIJN, Marc EHRIG, Cristina FEIER, Francisco MARTIN-RECUERDA, François SCHARFFE et Mortiz WEITEN. Semantic Web Technologies, trends and re-search in ontology-based systems, chapter Ontology Mediation, Merging, and Align-ing, pages 95-113. WILEY, 2006.

[11] Yannis KALFOGLOU et Marco SCHORLEMMER. If-map: an ontology mapping method based on information flow theory. Journal on Data Semantics, 1(1):98-127, october 2003.

[12] Alexander MAEDCHE, Boris MOTIK, Nuno SILVA et Raphael VOLZ. MAFRA - A Mapping Framework for Distributed Ontologies. In Proc. of 13th European Confer-ence on Knowledge Engineering and Knowledge Management (EKAW), Siquenca, Spain, 2002.

[13] Paolo BOUQUET, Fausto GIUNCHIGLIA, Frank van HARMELEN, Luciano SERAFINI et Heiner STUCKENSCHMIDT. Contextualizing ontologiesstar, open. Web Semantic: Science, Services and Agents on the World Wide Web, 1(4):325-343, 2004.

[14] Deborah MCGUINNESS, Richard FIKES, James RICE et Steve WILDER. The chimae-ra ontology environment. pages 1123-1124. AAAI Press / The MIT Press.

[15] Noy, N. F., \& Musen, M. A. (2000). Prompt: algorithm and tool for automated ontolo-gy merging and alignment. In Proceeding of Seventeenth National Conference on Arti-ficial Intelligence AAAI.

[16] Marc EHRIG et Steffen STAAB. Qom quick ontology mapping. In International Se-mantic Web Conference (ISWC2004), Japan, November 2004.

[17] Bach Thanh LE, Rose DIENG-KUNTZ et Fabien GANDON. On ontology matching problems - for building a corporate semantic web in a multi-community's organiza-tion. InICEIS (4), pages 236-243, 2004.

[18] Natalya NOY et Mark MUSEN. Anchor-prompt: Using non-local context for seman-tic matching, 2000.

[19] Bergamaschi, S., Castano, S., \& Vincini, M. (1999). Semantic integration of semistruc-tured and structured data sources. SIGMOD Record, 28(1). pp. 54-59. https://doi.org/10.1145/ 309844.309897

[20] Berners-Lee, T. (2001). The semantic web. Scientific american , pp. 284(5):35-43,

[21] Doan, A. H., Domingos, P., \& Halevy, A. (2001). Reconciling schemas of disparate da-ta sources: A machine learning approach. In Proceeding of SIGMOD. https://doi.org/10.1145/ $\underline{376284.375731}$ 
[22] Doan, A., Madhavan, J., \& Domingos, P. (2002, May 7-11). Learning to Map between ontologies on the Semantic Web. In : the eleventh International World Wide Web conference (WWW2002), Honolulu, Hawaii, USA. https://doi.org/10.1145/511446.511532

[23] Noy, N. F., \& Musen, M. A. (1999). Smart: Automated support for ontology merging and alignment. Technical Report SMI-1999-0813, Stanford Medical Informatics.

[24] François VERNADAT. Interoperable enterprise systems: Architectures, methods and metrics. Rapport technique, LGIPM, Université de Metz, France, 2007.

[25] Fabrice JOUANOT. A Semantic Model for the Interoperability of Information Sys-tems. INFORSID, pages 347-364, 2000.

[26] CHARLET, CORDONNIER and GIBAUD. Interoperability in medicine: when the content queries the container and the organization. Information - Interaction - Intelli-gence, 2 (2): 37-62, 2002.

[27] Daoudi, N., Ajhoun, R. An Adaptation of E-learning Standards to M-learning. Interna-tional Journal of Interactive Mobile Technologies (iJIM), Vol 2, No 3 (2008)

[28] Faqihi,B., Daoudi, N., Ajhoun, R. Towards the implementation of semantic interoper-ability of information systems via technique of matching: Issue and prospective (IMCL), pages 134-140, 2012

[29] WYGWAM Office of Technological Expertise. "Cloud Computing: Real revolution or simple evolution? »2012

[30] Naçima MELLAL. Making of the semantic interoperability of systems, based on on-tologies and information flows. PhD Thesis, University of SAVOIE, France, Decem-ber 2007.

[31] Christophe ROCHE. Terminology and ontology. Languages Review, No. 157, March 2005.

[32] Mr. Ben Henda, For Semantic Interoperability in Education: The Normative Models of ISO / IEC JTC1 SC36, University of Bordeaux 3.

[33] The Francophone Network project of Reusable Educational Resources (REFRER) funded by the International Organization of the Francophonie (OIF), launched in De-cember 2012 over 24 months: http://www.refrer.licef.ca/

[34] A. BATTOU "A granular approach to pedagogical objects for adaptability in the con-text of IT environments for human learning". PhD thesis in computer science. Faculty of Sciences Ibn Zohr, Morocco, 2012

[35] M. Fernandez, A. Gómez-Pérez, N. Juristo, METHONTOLOGY: from ontological art towards ontological engineering, Acts de AAAI, 1997.

[36] KHALFI Souheila, construction of an ontology for the care of patients at home. [Memory of magister]. [Online]. [Consulted on April 2, 2017]. Available on

[37] Michel Heon et al, Assisted Methodology of Designing an Ontology from a Semi-Formal Consensual Conceptualization. Pdf. LICEF Research Center, Télé-Université, Montreal, Canada. $1 \mathrm{p}$.

[38] S. Izza, Integration of industrial information systems, a flexible approach based on semantic services, doctoral thesis, School of Mines of Saint-Étienne, 2006.

[39] D. Konstantas, J.-P. Bourrières, M. Leonard, N. Boudjlida, 2005. Foreword by: In-teroperability of Enterprise Software and Applications, Proceedings of INTEROPESA '05, Geneva, Switzerland, Springer-Verlag, p. . v-vi, 21-25 February 2005.

[40] Leake D. B. (Editor), Case-Based Reasoning: Experiences, Lessons, and Future Direc-tions, AAAI Press / MIT Press, Menlo Park, CA, 1996.

[41] Riesbeck C., Shank R., Inside Case-Based Reasoning, Lawrence Erlbaum Associates, 1989.

[42] Fuchs B., Lieber J., Mille A., Napoli A., « An algorithm for adaptation in case-based reasoning. », Proceedings of ECAI'2000, Amsterdam, p. 45-49, 2000.

[43] Fuchs B., Lieber J., Mille A., Napoli A., "Towards a unified theory of adaptation in reasoning from cases. ", Actes de RàPC99, Palaiseau, France, p. 77-85, 1999. 
[44] Leake D. B., Smyth B., Yang Q., Wilson D., Special Issue on Maintaining Case-Based Reasoning Systems, Computational Intelligence, Vol. 17, No. 2, 2001. https://doi.org/10.1111/ $\underline{0824-7935.00139}$

[45] L.Lamontagne, G.Lapalme "Reasoning based on textual cases - state of the art and per-spectives -", Review of artificial intelligence. Volume X - No. X/2002, pages 1 to X, University of Montreal, Quebec, Canada.

[46] THOT: Directory of Distance Learning Platforms: http://thot.cursus.edu/rubrique.asp?no=24735

[47] PLUME sheet http://www.projet-plume.org/ganesha;

[48] Cancore is a standard compatible with the LOM data description model: http://fr.wikipedia.org/wiki/CanCore

[49] NORMETIC is a "metadata standard for the description of teaching and learning re-sources: http://www.normetic.org

[50] Gilbert Paquette, Claude Coulombe, Monique Charpentier LICEF Research Center, Téléuniversité, "Integration of CLOMs in a remote university - Experimentation back to TELUQ" - International Journal of Technologies in Higher Education 2016.

\section{$7 \quad$ Authors}

Brahim Faqihi was born in 1973 in Morocco. In 2004, he got his depth graduate degree in Software Engineering and Advanced Technology of Information at engineers Mohammedia school in Rabat. Her thesis is entitled : "Aid tools to indexing : Canonical form and business concepts. In 2009, he got his master specializing in human resources management at the Higher Institute of Commerce and Business Administration in Casablanca. Her thesis is entitled: "Towards the establishment of a staff appraisal system of company." He has published the following articles:

"Towards the implementation of semantic interoperability of information systems via technique of matching: Issue and prospective", Amman-Jordan, 7th International Conference on Interactive Mobile and Computer Aided Learning Princess Sumaya University for Technology 6-8 November 2012.

"Semantic Interoperability in the d-learning in the era of Cloud Computing: Simplicity or Complexity". International Conference Learning ICL, Kazan, Republic of Tatarstan, Russia, 25-27 September 2013.

Between 2005 and 2009, he was temporary teacher of computer science at the University Hassan II in Casablanca. Since 2010, he is an active member on research structure : learning and research in mobile age. He is a Phd Student at the fourth year. His research topic is the semantic interoperability between the learning information systems in cloud era.

He is currently with SSL, NSCSSA (National School of Computer Science and Systems Analysis), University Mohammed V - Souissi Rabat Morocco (email: brahimfaqihi@hotmail.com).

Najima Daoudi: Born in 1976 in Morocco. She is PhD at ENSIAS. Rabat, Morocco. The thesis entitled "MADAR Learning: interoperable environment between E-learning and M-learning." 2009. Diploma of Higher Studies. EMI, Rabat, Morocco. 2004 Engineer Degree at INSEA, Rabat, Morocco. 1999. Professor assistant in ESI since December 2000 . 
MADAR learning: an interoperable environment for E\&M learning. IEEE Engineering Education 2010. The Future of Global Learning in Engineering Education 14-16 April 2010 in Madrid/Spain.

Tutoring 2.0: How to improve tutoring system by using web mining? INTED: the international technology, education and development conference, Valencia, Spain, March, 2013

Role of Model of excellence to improve d-learning projects. Else International scientific conference elerning software for education, Bucharest, April 25th - 26th, 2013.

How to Promote Learning in African Countries? Open d-learning System Based on an Open Content. IJET: International Journal of Emerging Technologies in Learning (iJET) vol $8 \mathrm{~N}^{\circ} 4$. August 2013.

She is currently with SSL, NSCSSA (National School Of Computer Science And Systems Analysis) and with LYRICA, SIS (School Of Information Sciences), University Mohammed V - Souissi Rabat Morocco (email: daoudinajima@yahoo.fr).

Rachida Ajhoun was born in Morocco. She got Computer Science Engineer degree from EMI School (Mohammadia School of Engineering). $\mathrm{PhD}$ in Computer Science and E-learning at University of Mohammed V. Prof. Ajhoun has published articles and books about E-learning and teaches at the ENSIAS School. Prof. Ajhoun is a Senior Member of IEEE, director of MSIWeb Master at ENSIAS, director of the E-learning Center at University of Mohammed V, director of LeRMA (Learning and Research in Mobile Age) team. She has founded the GUIDE (Global University In Distance Education) association and she was a director of e-NGN (E-Next Generation Networks) association.

She is currently with SSL, NSCSSA (National School of Computer Science and Systems Analysis), University Mohammed V - Souissi Rabat Morocco (email: ajhoun@gmail.com).

Article submitted 28 May 2018. Final acceptance 03 August 2018. Final version published as submitted by the authors. 